\title{
Integrating problem-based learning with schoology in criminal law course
}

\author{
Dzul Rachman ${ }^{1 *}$, Rio Arif Pratama ${ }^{1}$, Ni Wayan Surya Mahayanti ${ }^{2}$, I Putu Indra Kusuma ${ }^{3}$ \\ ${ }^{1}$ Universitas Muhammadiyah Kalimantan Timur. Jalan Ir. H. Juanda No 15 Samarinda, Indonesia \\ ${ }^{2}$ Universitas Pendidikan Ganesha. Jalan Udayana No.11, Buleleng, Bali 81116, Indonesia \\ ${ }^{3}$ Western Michigan University. 1903 Western, Michigan Ave, Kalamazoo, MI 49008, United States \\ * Corresponding Author. E-mail:dr650@umkt.ac.id
}

Received: 7 December 2019; Revised: 6 January 2020; Accepted: 7 April 2020

\begin{abstract}
This study indents to investigate students' perception of problem-solving skills and the influence of Schoology on students' ability to solve problems used in the criminal course in tertiary education. In reality, this course requires many activities involving students to solve various types of cases. This study used the quasi-experimental method in the class of criminal law. The students were from the Faculty of Law, taking a 14 week enrolled in the Criminal course in the second semester. The instruments in this study were tests and questionnaires. Data were analyzed using descriptive and inferential analysis. Overall, there are significant differences in problem-solving skills between the students who learn the material of solubility and constant solubility products using the Problem-solving learning model through Schoology in the learning activities. Furthermore, this learning model can also be applied to overcome the lack of time allocation for face-to-face learning.
\end{abstract}

Keywords: project-based learning; law study; Schoology; problem-solving

How to Cite: Rachman, D., Pratama, R., Mahayanti, N., \& Kusuma, I. (2020). Integrating problem-based learning with schoology in criminal law course. Psychology, Evaluation, and Technology in Educational Research, 2(2), 90-97. doi:http://dx.doi.org/10.33292/petier.v2i2.35

\section{INTRODUCTION}

In the digital era, when technologies rapidly develop, people indulge in many conveniences that the technologies have provided. Communication and interaction become easier due to the invention of internet technology and sophisticated communication devices. These technological changes have some effects on various fields, including education as well as teaching (Rachman \& Setiawan, 2016). Low (2017) stated that teaching and learning are emphasized on learning rather than on teaching where the role of teachers will be the facilitators, knowledge navigators, and co-learners rather than the knowledge transmitters. The advanced technologies could ease the shifting of teacher roles as well as education practitioners. It also can enhance their roles in facilitating learning by utilizing the technologies. Bernard (2017) suggested that new technologies like artificial intelligence and educational software have changed some aspects of education, like transforming the field for students, restructuring the educator roles, developing changes in approaches to teaching and re-modelling classrooms.

As the law students are adult learners, they are expected to solve problems and become independent as they progress throughout their education (Johnsen et al., 2009; Niedwiecki, 2012). Those skills are particularly valuable for their development. According to Anderson (1982) stated that learning environments should be built to focus more on problem-solving as it brings about more learning. There are a lot of legal subject learning materials that students must absorb in a relatively limited time. This situation makes the learning to be limited to memorization without understanding the concepts that exist. In reality, criminal course requires many activities involving students to solve various types of cases. According to the observation of researchers, the ability to solve problems by students has not been well developed, such as lack of ability in asking questions, answering questions, analysing arguments, looking for valid evidence (valid), and making conclusions. Problem-based 
learning (PBL) is a learning model that can facilitate these activities. PBL offers a great tool for students' self-instruction (Orsmond \& Zvauya, 2015). Moreover, the PBL research to propose an integrative framework for leadership development design and evaluation. Although authors have noted that group- and individual-level factors influence learning outcomes (Loyens et al., 2012). According to Yeen-Ju et al. (2015) found that students' problem-solving skills were enhanced when the learning environment was one that incorporated authentic learning strategies and was supported by face to face as well as online learning environments. A review of the literature shows that PBL has increasingly been trialled and adopted across a diversity of educational institutions worldwide, advantages and disadvantages of PBL (Hermawan et al., 2018; Hudha et al., 2018; Lee et al., 2009; Pereira et al., 2017; Wilkinson, 2014).

Problem-based learning (PBL) is an instructional method that engages students and allows them to bring their assignments to the group for discussion, collaboration, and consensus (Grigg \& Lewis, 2018; Naidu \& Oliver, 1996; Rusman, 2011). In line with Romito and Eckert (2011) PBL contributes to developing such skills in several ways, as it asserts that learners form meaning and comprehension from their interactions both with others and through their experiences in an active learning mode.

In solving the problem not only using the formulas that have been obtained, but also using reasoning activities, analysis, critical thinking in processing that have been obtained to get a way out in solving the problem (Pólya, 2014). In PBL, knowledge is actively built by the learner; students are, therefore, not passive (Gregson et al., 2010; Isrokijah, 2016; Liza et al., 2011). Students also seek and become active in scrutinizing and constructing knowledge. Furthermore, students face alternative viewpoints by interacting with other students in small groups, thus constructing new modes of learning (McCarlie \& Orr, 2010; Nadershahi et al., 2013).

Current research indicates that most graduates have problems securing a job due to a lack of problem-solving skills and communication skills that are highly sought after by the industry (Tan et al., 2009). According to Jonassen (2004), learning environments should be built to focus more on problem-solving as it brings about more learning. Learning environments that focus on problemsolving also tend to encourage students to utilize existing knowledge to explore possible solutions to a problem. That process of problem-solving allows students to gain new knowledge and consolidate new knowledge with prior knowledge (Merrill, 2002, 2007, 2012). Research also provides evidence that web technologies are becoming increasingly important aspects when designing learning environments (Lunenburg, 2011). However, the implementation of web technologies into a learning environment still requires a sound theoretical framework for its benefits to be realized (Moscinska \& Rutkowski, 2011). Therefore, colleges and universities begin to rely on authentic learning strategies as authentic learning can create a learning environment that enables students to gain important higher-order thinking skills and complex communication, which would help graduates when they enter the working world (Lombardi, 2007).

Today, higher education institutions face many challenges, including the increasing number of students in their education. Learning management systems (LMS) can be useful for adjusting increased enrolment, varying lessons, and supporting student learning (Dobre, 2015). Ngeze (2016) argues that the use of learning management systems in higher education is of great importance to both students and lecturers. In Additional recent studies that examined the users' perspective found that LMSs are helpful for the convenience of learning, have a positive contribution to the learning process (Ghilay, 2016) and are effective tools to facilitate learning because of their interactive environment and availability (Kurata et al., 2018).

Schoology is a learning management system that provides facilities to teachers and students to interact in a learning environment through online social networks (Jalinus \& Ambiyar, 2016). Schoology is an online learning, classroom management, and social networking platform that attempts to improve learning through better communication, collaboration, and increased access to curriculum and supplemental content (Biswas, 2013). Schoology is free and allows the teacher to teacher, teacher to student, and even student to student online collaboration in a user-friendly and secure environment. It offers the possibility of adopting this collaboration and learning tool to customize learning for each student (Firmington Schology, 2014).

An educational virtual classroom environment has been defined as one that affords the potential to carry out asynchronous and synchronous learning. In contrast, problem-based learning (PBL) is used as the process to implement the planned scenarios, such as case studies, as well as to aid learning 
Psychology, Evaluation, and Technology in Educational Research, 2 (2), 2019, 92

Dzul Rachman, Rio Arif Pratama, Ni Wayan Surya Mahayanti, I Putu Indra Kusuma

in a multi-disciplinary or multi-skills context (Bignell \& Parson, 2010). There was an increase in learning outcomes of students using Schoology assisted learning (Aminoto \& Pathoni, 2014). The learning that utilizes technology in the form of the web can improve students' problem-solving abilities. Other than students learning context, Pumphrey and Slater (2002) claimed that technology advancement is also a factor that causes the development of critical thinking and problem-solving skill being less efficient. With the technology advancement, students can get access to all the information through the internet, which then causes negative effect as they simply adopt the information without analyzing, interpreting and thinking critically (Purcell et al., 2012). It also hinders their ability to solve the problems because the internet offers most of the solutions. For the reasons mentioned earlier, this study intends to investigate students' perception of problem-solving skills and the influence of Schoology on students' ability to solve problems.

\section{METHOD}

\section{Research Design Selecting}

This study used the quasi-experimental method with one group design pre-test and post-test conducted at the class of criminal law. According to Creswell (2013), "quasi-experiments include assignment, but not a random assignment of participants to groups. In this study, there are two variables, namely the independent variable and the dependent variable. The independent variable in the study was ICT-assisted PBL while the dependent variable was the problem-solving ability. The research design used was a pretest-posttest control group design.

The students were from the Faculty of Law, taking a 14-week enrolled in the Criminal course (Access code of Schoology BNQR-J2V4-BGCC6). The class comprised of 84 students from various ethnic backgrounds. 54 participants are female students and the rest 30 are male students. In the online classroom, the lecturer would have weekly discussions with the class on various related topics; students would have group discussions and consultation sessions with the lecturer.

The instruments in this study were tests and questionnaires. An instrument is a tool for measuring, observing, or documenting quantitative data (Creswell, 2013). Creswell (2013) also stated that the researchers use instruments to measure achievement, assess individual ability, observe behaviour, develop a psychological profile of an individual, or interview a person. The problemsolving skills test was in the essay form. The indicators of problem-solving skills used in essay form understood the problem, devising a plan, carrying out the plan, and looking back. The judgment of five validators determines the validity of the instrument. The validators were four law lecturers. Based on a calculation using the equations CVR (Content Validity Ratio), the obtained result was $=1$. The result still acceptable reliability coefficient used here is $\geq 0.65$ (Merilia et al., 2019; Swerdlik \& Cohen, 2005). This result indicates that the instrument of the problem-solving skills test was valid. Data were analysed using descriptive and inferential analysis. The inferential analysis used in this research was a t-test.

The self-assessment test consisted of questions about the PBL approach used during the intervention. The main objective of that kind of assessment was to seek students' opinions about using the PBL approach and to find out which learning outcomes they felt they had achieved. The selfassessment test and questionnaire were used to elicit the views of students about the use of PBL and how they see learning by using cases are considered appropriate methods (Dolmans et al., 1998). Data obtained from the study were coded, computed, and analysed descriptively using the Statistical Packages for Social Science (SPSS).

\section{RESULT AND DISCUSSION}

\section{Result}

Based on the t-test results, the pre-test mean is 67.67. As for the value of the post-test, it obtained a mean of 80.94. According to the results, pre-test $67.67<80.94$ post-test, it can be concluded that there are differences in the average test results between pre-test and post-test, which means the use of Schoology has a positive impact in teaching English in the Law Study Program.

The results in Table 1 show that the relationship between the pre-test and post-test variables. Based on these results, it is found that the correlation coefficient is equal to the significance (Sig.). 
Psychology, Evaluation, and Technology in Educational Research, 2 (2), 2019, 93

Dzul Rachman, Rio Arif Pratama, Ni Wayan Surya Mahayanti, I Putu Indra Kusuma

The value of Sig. $0.001<$ probability 0.05 , it can be said that there is a relationship between the use of Schoology to the results of the post-test of Law study program students. It is also supported by the results of the Paired Samples Test and Pearson Correlation.

Table 1. Descriptive Statistic

\begin{tabular}{clcccc}
\hline \multicolumn{5}{c}{ Paired Samples Statistics } \\
\hline \multirow{2}{*}{ Pair 1 } & Mean & $\mathrm{N}$ & Std. Deviation & Std. Error Mean \\
& pretest & 67.67 & 84 & 9.97 & 1.424 \\
& posttest & 80.49 & 84 & 8.181 & 1.169 \\
\hline
\end{tabular}

Table 2. Result of t-test

\begin{tabular}{llcc}
\hline & & Pretest & Posttest \\
\hline Pretest & Pearson Correlation & 1 & $.449^{* *}$ \\
& Sig. (2-tailed) & & 0.001 \\
\multirow{3}{*}{ Posttest } & N & 84 & 84 \\
& Pearson Correlation & $.449^{* *}$ & 1 \\
$* *$ Correlation is significant at the 0.01 level (2-tailed). & 0.001 & 84 \\
\hline
\end{tabular}

Based on the Sig (2-tailed) value, $0.001<0.05$, it means that there is a significant correlation between the use of Schoology and the results of the post-test of UMKT Law study program students. The table also shows the calculated r-value, which is equal to 0.449 . Then the results of comparison with the value of $r$ table obtained are as follows; $r$ count $0.449>0.281 \mathrm{r}$ table. The conclusion that can be obtained is that there are positive impacts and significant changes from the usage of Schoology after the pre-test is done, which increases the post-test results of students of the Law study program at UMKT. So, the use of Schoology is considered useful in teaching and improving the learning outcomes of UMKT Law study program students.

\section{Student's Perceptions of the PBL Module}

In the first section, the students from the experimental group were asked to evaluate their experience of the PBL program. On a scale of five (1-very negative to 5 -very positive), the mean score on their experience was computed at 4.20. On the whole, the students had a very positive perception of PBL as an approach. Table 3 shows the mean scores of the ten items.

Table 3. Students' Perception of PBL

\begin{tabular}{cllcc}
\hline No. & \multicolumn{1}{c}{ Statement } & Mean & SD & Interpretation \\
\hline 1. & The problems allowed the application of learning to real-world situations & 4.34 & 0.48 & Very positive \\
2. & The problems promoted to working with others & 4.28 & 0.68 & Very positive \\
3. & The problems stimulated continuous acquisition of new and relevant & 4.44 & 0,50 & Very positive \\
& knowledge & 4.23 & 0,62 & Very positive \\
4. & Overall, I am satisfied with the program & 4.07 & 0,62 & Positive \\
5. & Overall, my learning experience was stimulating & 4,20 & 0,79 & Positive \\
6. I participated actively in my group meetings & 3,94 & 0,50 & Positive \\
7. & I was motivated to learn and use the English language throughout the & 4,10 & 0,65 & Positive \\
& process of problem-solving & 4,41 & 0,56 & Very positive \\
8. & I could find the learning resources for the problem & 4,06 & 0,62 & Positive \\
9. I was motivated to manage the problem & 4,20 & 0,54 & Very positive \\
10. I had sufficient time to manage the problem & average & &
\end{tabular}

Students reported the highest mean for item 3: The problems stimulated the continuous acquisition of new and relevant knowledge $(\mathrm{m}=4.44)$. The majority agreed that the problems in the PBL stimulated the continuous acquisition of new and relevant knowledge. Besides, the students were motivated to manage the $(\mathrm{m}=4.41)$. It appeared that the problems allowed the application of learning to real-world situations $(\mathrm{m}=4.34)$, causing them to work with others $(\mathrm{m}=4.28)$.

The other four items had lower mean scores but still showing positive perceptions of the PBL program. They were also able to find the resources needed $(\mathrm{m}=4.10)$ and were motivated to solving the 
Psychology, Evaluation, and Technology in Educational Research, 2 (2), 2019, 94

Dzul Rachman, Rio Arif Pratama, Ni Wayan Surya Mahayanti, I Putu Indra Kusuma

problem $(\mathrm{m}=4.06)$. Finally, the lowest score was for item 7 on the students agreed to a certain extent that they were motivated to learn and use English throughout the process of problem-solving $(\mathrm{m}=3.94)$. This aspect of use English throughout the process of problem-solving can be understood as one limitation of this study in that the students were often too embarrassed or shy to say anything when they do not understand another speaker or when they realized that a conversation partner had not understood them.

\section{Discussion}

The results showed that problem-based learning via a virtual learning environment enhanced learning ability and problem-solving skills among students in the criminal law course. Student feedback toward the model was positive, as it followed their interests and used problem-solving to stimulate learning. Findings from the statistical analysis confirm that students who learned in the online learning environment achieved a better score $(\mathrm{M}=80.49, \mathrm{SD}=8.181)$. A further effect showed that there was a medium effect of Schoology towards students' problem-solving skills. It suggests that there are other potential influencing variables in the teaching and learning process. A more investigation on factors, like facilities, lecturer's strategies, and students' input were suggested.

In this study, students who were taught with Schoology able to develop a more logical argument and critical to particular problems. It is contrary with what (Pumphrey \& Slater, 2002) and Purcell et al. (2012) who mentioned that technology can be a negative factor in developing students' critical thinking. The active discussions during the online classroom helped the students to interact within the virtual class (Jalinus \& Ambiyar, 2016; Kurata et al., 2018) and develop their problem-solving skills. Schoology is online learning, classroom management, and social networking platform that attempts to improve learning through better communication, collaboration, and increased access to the curriculum and supplemental content. Through Schoology, students can download material that has been uploaded by the teacher in Schoology. Also, Schoology provided learning videos to attract and facilitate students in independent learning (Firmington Schology, 2014). In line with Gök and Sýlay (2010) concluded that problem solving strategies was more effective in cooperative learning than conventional teaching.

The ICT-assisted problem orientation stage is using authentic problems or cases as a learning context, which is presented in the form of a short video recording. At this stage, students are trained to identify problems by linking basic concepts, making a list of known quantities, and determining the quantities that are asked correctly. It is in line with the opinion of (Khoiri, 2013; Khoiri et al., 2013), who states that by presenting ICT-assisted real-world problems, students are more interested in identifying these problems. Examples of questions that will help students in forming knowledge and understanding the material as well as examples of problem-solving problems that will stimulate students to have discussions are presented in Schoology. In addition to being given examples of questions, in the material, questions that must be tried by students are provided. These features can facilitate students in learning independently and also help students to become more enthusiastic in participating in learning because so far, most students feel saturated and bored with material that is always presented through textbooks. It can develop students' knowledge and students' problem-solving abilities.

Besides, there were several limitations to this study. First, although the results of this study revealed significant intervention effects on problem-solving skills, the generalization of study findings is limited due to the small number of participants who attended the course. Future research should examine the effect of PBL with ICT with different types of students (e.g., various grade levels, primary) and various skills.

\section{CONCLUSION}

Based on the explanation above, it is clear that the PBL model assisted by ICT is able to accommodate indicators of students' problem-solving abilities. In addition, students are also trained to think convergently by using logical-critical reasoning in considering or formulating the most appropriate answers. There are significant differences in problem-solving skills between the students who learn the material of solubility and constant solubility products using the Problem-solving learning model through Schoology in the learning activities. 
The lecturer, especially in the law course, can consider implementing the problem of learning a solving Schoology model to develop problem-solving skills and to optimize students' learning outcomes. Furthermore, this learning model can also be applied to overcome the problem of time management as it minimizes time consumed by face-to-face learning.

\section{ACKNOWLEDGMENTS}

This publication was supported by grant number 515.23/LPPM/A.4/C/2019 from Ministry of Research and Technology Indonesia (Ristekdikti).

\section{REFERENCES}

Aminoto, T., \& Pathoni, H. (2014). Penerapan media e-learning berbasis schoology untuk meningkatkan aktivitas dan hasil belajar materi usaha dan energi di kelas XI SMA N 10 Kota Jambi. Sainmatika: Jurnal Sains Dan Matematika Universitas Jambi, 8(1).

Anderson, J. R. (1982). Acquisition of cognitive skill. Psychological Review, 89(4), 369-406. https://doi.org/10.1037/0033-295X.89.4.369

Bernard, Z. (2017). Here's how technology is shaping the future of education. Business Insider. https://www.businessinsider.sg/how-technology-is-shaping-the-future-of-education-201712? $\mathrm{r}=\mathrm{US} \& \mathrm{IR}=\mathrm{T}$

Bignell, S., \& Parson, V. (2010). Best practice in virtual worlds teaching: A guide to using problembased learning in second life. http://previewpsych.org/BPD2.0.pdf

Biswas, S. (2013). Schoology-supported classroom management: A curriculum review. Northwest Journal of Teacher Education, 11(2), 12. https://doi.org/10.15760/nwjte.2013.11.2.12

Creswell, J. W. (2013). Educational research: Planning, conducting, and evaluating quantitative and qualitative research. Pearson.

Dobre, I. (2015). Learning management systems for higher education - An overview of available options for higher education organizations. Procedia - Social and Behavioral Sciences, 180, 313-320. https://doi.org/10.1016/j.sbspro.2015.02.122

Dolmans, D. H. J. M., Wolfhagen, I. H. A. P., \& Van Der Vleuten, C. P. M. (1998). Thinking about student thinking: motivational and cognitive processes influencing tutorial groups. Academic Medicine, $73(10)$

S22-24. https://journals.lww.com/academicmedicine/Citation/1998/10000/THINKING_ABOUT_STUD ENT_THINKING_Motivational_and.34.aspx

Firmington Schology. (2014). What is schoology? Customized Learning: Through Use of Technology. https://sites.google.com/site/farmingtonschoology/what-is-schoology

Ghilay, Y. (2016). Online learning in higher education. Nova Science Publishers, Incorporated.

Gök, T., \& Sýlay, I. (2010). The effects of problem solving strategies on students' achievement, attitude and motivation. Latin-American Journal of Physics Education, 4(1), 7-21. https://dialnet.unirioja.es/servlet/articulo?codigo $=3694877$

Gregson, K., Romito, L. M., \& Garetto, L. P. (2010). Students' attitudes toward integrating problembased learning into a DDS pharmacology curriculum. Journal of Dental Education, 74(5), 489 498. http://www.jdentaled.org/content/74/5/489.short

Grigg, R., \& Lewis, H. (2018). Moving the andragogy of teacher educators forward: the potential and challenges of Problem-Based Learning in teacher education. Journal of Problem-Based Learning, 5(1), 5-20. https://doi.org/10.24313/jpbl.2018.5.1.5

Hermawan, H., Samsuri, S., Kurniawati, D. P., Sofyaningsih, V., \& Prasetyo, D. (2018). The use of the controversial public issue learning model with videos and a macromedia flash player on Civic Education. Psychology, Evaluation, and Technology in Educational Research, 1(1), 1930. https://doi.org/10.33292/petier.v1i1.2

Hudha, M. N., Hakim, A. R., Aji, S. D., Tasi, M. I., Sundaygara, C., Laksana, E. P., Fajaruddin, S., Andi, T., Yusro, A. C., \& Chaeruman, U. A. (2018). Scientific performance e-rubric-assisted problem-based learning for improving learning effectiveness. In International Journal of 
Engineering \& Technology (Vol. 7). www.sciencepubco.com/index.php/IJET

Isrokijah, I. (2016). Developing problem-based learning (PBL) worksheets for the eight grade students at junior high school. LLT Journal: A Journal on Language and Language Teaching, 18(2), 99106.

Jalinus, N., \& Ambiyar, A. (2016). Media dan sumber pembelajaran. Kencana.

Johnsen, D. C., Finkelstein, M. W., Marshall, T. A., \& Chalkley, Y. M. (2009). A model for critical thinking measurement of dental student performance. Journal of Dental Education, 73(2), 177183. http://www.jdentaled.org/content/73/2/177.short

Jonassen, D. H. (2004). Learning to solve problems: An instructional design guide. John Wiley \& Sons.

Khoiri, W. (2013). Implementasi model problem based learning berbantuan multimedia untuk meningkatkan kemampuan berpikir kreatif siswa kelas VII SMP Negeri 4 Kudus pada materi segitiga [Universitas Negeri Semarang]. https://lib.unnes.ac.id/18832/

Khoiri, W., Rochmad, R., \& Cahyono, A. N. (2013). Problem-based learning berbantuan multimedia dalam pembelajaran matematika untuk meningkatkan kemampuan berpikir kreatif. Unnes Journal of Mathematics Education, 2(1). https://doi.org/10.15294/ujme.v2i1.3328

Kurata, Y. B., Bano, R. M. L. P., \& Marcelo, M. C. T. (2018). Effectiveness of learning management system application in the learnability of tertiary students in an undergraduate engineering program in the Philippines. In T. Andre (Ed.), Advances in Human Factors in Training, Education, and Learning Sciences. AHFE 2017. Advances in Intelligent Systems and Computing (Vol. 596, pp. 142-151). Springer. https://doi.org/10.1007/978-3-319-60018-5_15

Lee, G.-H., Lin, Y.-H., Tsou, K.-I., Shiau, S.-J., \& Lin, C.-S. (2009). When a problem-based learning tutor decides to intervene. Academic Medicine, 84(10), 1406-1411. https://doi.org/10.1097/ACM.0b013e3181b6b433

Liza, A. N., Karomiah, W., Abdullah, W., \& Yunita, A. (2011). Would problem-based learning affect students'generic competencies? African Journal of Education and Technology, 1(3), 1-14.

Lombardi, M. M. (2007). Authentic learning for the 21st century: An overview. In D. G. Oblinger (Ed.), EDUCAUSE Learning Initiative (ELI) (Vol. 1). https://library.educause.edu/resources/2007/1/authentic-learning-for-the-21st-century-anoverview

Low, P. (2017). E-learning implementation in foundation English class: Learners' perspectives and learning achievement. International Journal of Computer Theory and Engineering, 9(4), 285289. https://doi.org/10.7763/IJCTE.2017.V9.1153

Loyens, S. M. M., Kirschner, P. A., \& Paas, F. (2012). Problem-based learning. In APA educational psychology handbook, Vol 3: Application to learning and teaching. (pp. 403-425). American Psychological Association. https://doi.org/10.1037/13275-016

Lunenburg, F. C. (2011). Critical thinking and constructivism techniques for improving student achievement. National Forum of Teacher Education Journal, 21(3), 1-9.

McCarlie, V. W., \& Orr, D. L. (2010). Health science education: reviewing a framework for problembased learning. Journal of Dental Education, 74(5), 480-488. http://www.jdentaled.org/content/74/5/480

Merilia, S., Fajaruddin, S., \& Arbain, A. (2019). An assessment of an English textbook of vocational school. Arisen: Assessment and Research on Education, 1(2). https://doi.org/10.33292/arisen.v1i2.46

Merrill, M. D. (2002). First principles of instruction. Educational Technology Research and Development, 50(3), 43-59. https://doi.org/10.1007/BF02505024

Merrill, M. D. (2007). First principles of instruction: A synthesis. Trends and Issues In Instructional Design and Technology, 2, 62-71.

Merrill, M. D. (2012). First principles of instruction. John Wiley \& Sons.

Moscinska, K., \& Rutkowski, J. (2011). Barriers to introduction of e-learning: A case study. 2011 
Psychology, Evaluation, and Technology in Educational Research, 2 (2), 2019, 97

Dzul Rachman, Rio Arif Pratama, Ni Wayan Surya Mahayanti, I Putu Indra Kusuma

IEEE Global Engineering Education Conference (EDUCON), 460-465. https://doi.org/10.1109/EDUCON.2011.5773176

Nadershahi, N. A., Bender, D. J., Beck, L., Lyon, C., \& Blaseio, A. (2013). An overview of case-based and problem-based learning methodologies for dental education. Journal of Dental Education, 77(10), 1300-1305. http://www.jdentaled.org/content/77/10/1300.short

Naidu, S., \& Oliver, M. (1996). Computer-supported collaborative problem-based learning: An instructional design architecture for virtual learning in nursing education. Journal of Distance Education, 11, 1-22. http://www.ijede.ca/index.php/jde/article/download/251/444?inline=1

Ngeze, L. V. (2016). Learning management systems in higher learning institutions in Tanzania: Analysis of students' attitudes and challenges towards the use of UDOM LMS in teaching and learning at the University of Dodoma. International Journal of Computer Applications, 136(11), 9-12. https://doi.org/10.5120/ijca2016908560

Niedwiecki, A. (2012). Teaching for lifelong learning: Improving the metacognitive skills of law students through more effective formative assessment techniques. Cap. UL Rev., 40, 149.

Orsmond, P., \& Zvauya, R. (2015). Community of learners: charting learning in first year graduate entry medical students during problem-based learning (PBL) study. Advances in Health Sciences Education, 20(2), 479-497. https://doi.org/10.1007/s10459-014-9542-4

Pereira, M. A. C., Barreto, M. A. M., \& Pazeti, M. (2017). Application of project-based learning in the first year of an industrial engineering program: lessons learned and challenges. Production, 27(spe). https://doi.org/10.1590/0103-6513.223816

Pólya, G. (2014). How to solve it: A new aspect of mathematical method. Princeton University Press.

Pumphrey, J., \& Slater, J. (2002). An assessment of generic skills needs. Department for Education and Skills. http://hdl.voced.edu.au/10707/102521

Purcell, K., Rainie, L., Heaps, A., Buchanan, J., Friedrich, L., Jacklin, A., Chen, C., \& Zickuhr, K. (2012). How teens do research in the digital world. Pew Internet \& American Life Project; ERIC. https://www.pewresearch.org/internet/2012/11/01/how-teens-do-research-in-the-digitalworld/

Rachman, D., \& Setiawan, I. (2016). Students' problems and experience on prezi. Script Journal: Journal of Linguistic and English Teaching, 1(2), 83-95. https://doi.org/10.24903/sj.v1i2.32

Romito, L. M., \& Eckert, G. J. (2011). Relationship of biomedical science content acquisition performance to students' level of PBL group interaction: Are students learning during PBL group? Journal of Dental Education, 75(5), 653 LP - 664.

Rusman, R. (2011). Model-model pembelajaran: Mengembangkan profesionalisme guru. Rajawali Pers.

Swerdlik, M. E., \& Cohen, R. J. (2005). Psychological testing and assessment: An introduction to tests and measurement. McGraw-Hill.

Tan, O.-S., Teo, C.-T., \& Chye, S. (2009). Problems and creativity. In O.-S. Tan (Ed.), Problem-based learning and creativity (pp. 1-14). Cengage Learning Asia Pte Ltd.

Wilkinson, J. (2014). The role of project-based learning in promoting environmental stewardship: A case study of Bahrain Teachers College. Journal of Sustainability Education, 7. http://www.susted.com/wordpress/content/the-role-of-project-based-learning-in-promotingenvironmental-stewardship-a-case-study-of-bahrain-teachers-college_2014_12/

Yeen-Ju, H. T., Mai, N., \& Selvaretnam, B. (2015). Enhancing problem-solving skills in an authentic blended learning environment: A Malaysian context. International Journal of Information and Education Technology, 5(11), 841. 